\title{
DISCURRIR ASOCIATIVO EN LA ESPAÑA CONTEMPORÁNEA (1839-1941)
}

\section{ELENA MAZA ZoRRILLA}

\author{
Valladolid, 2017, Universidad de Valladolid, 2017, 250 páginas.
}

ISBN: 978-84-8448-937-5

La profesora Elena Maza, con una trayectoria reconocida, dentro y fuera de España, por, entre otros, el impulso que ha venido dando a las investigaciones sobre el asociacionismo y la sociabilidad, como prueban diferentes seminarios internacionales por ella organizados, publicaciones, proyectos de investigación, etc., ha acertado a reunir los conocimientos y reflexiones que ha acumulado sobre ambas vertientes de la acción humana en la historia (tan conectadas entre sí) en un ciertamente útil y oportuno libro enfocado sobre la compleja y, en modo alguno, lineal, trayectoria seguida por el asociacionismo español entre dos fechas significativas, 1839, en que el naciente estado liberal, a través de una Real Orden abrió el camino para la existencia legal de asociaciones obreras limitando no obstante su objeto a la prestación, entre sus miembros, de socorros mutuos para casos de enfermedad, vejez, etc., y 1941 en que otra norma, también de rango inferior y de carácter interino (un decreto) derogó de hecho la normativa liberal en materia asociativa que había venido rigiendo hasta entonces y en la que la ley de 1887 había sido pieza capital, abocando a la cancelación en el registro y la supresión efectiva de innumerables asociaciones, de muy diferente signo, que habían florecido en todo el periodo anterior a la Guerra Civil de 1936-39.

Un libro muy útil, decíamos, tanto para el investigador en estas materias dada la exigente puesta al día en materia de conceptos, de líneas de trabajo, de bibliografía en lo que respecta a la historia, lógicamente, pero también al derecho (desde el momento en que, en la época contemporánea, asociarse acabó siendo reconocido como un derecho del individuo, dentro de un marco regulado y definido por el Estado), a la sociología, a la antropología y en fin, a cuantas disciplinas tocan con las prácticas de sociabilidad y de la vida asociativa en la que a menudo aquellas se traducen. Pero útil, asimismo, para el estudiante en razón de la claridad expositiva, de la capacidad de síntesis o del acompañamiento a los capítulos propiamente de explicación, de un extenso y bien ordenado apéndice en el que la autora recoge un conjunto de reglamentos correspondientes a otras tantas asociaciones, ordenados según nueve tipos distintos, que irían desde las entidades cuyo objeto consistía en facilitar el recreo y el ocio a sus miembros, a las sociedades de resistencia puestas en pie por los obreros 
organizados, las sociedades patronales, los grupos de presión, las asociaciones de tipo confesional, caritativo o benéfico, las entidades mutualistas, etc. Si ya la recopilación de estos variados reglamentos responde a una laboriosa búsqueda en archivos y bibliotecas de variado signo, la misma se enriquece con el añadido de una cuidada selección de imágenes como sellos, títulos de socio, credenciales manuscritas, etc., que permiten adquirir una visión aún más completa y rica del tema abordado en el libro.

El estudio propiamente dicho comprende los tres primeros capítulos del libro: en el primero, titulado como "Sociabilidad", la autora logra, en menos de veinte páginas, ofrecer una autorizada puesta al día, tanto de la introducción de este concepto en el horizonte de los intereses de los historiadores -no solo de los contemporaneístas- lo que fue obra de Maurice Agulhon, de su recepción en distintas historiografías nacionales, del inicial retraso español, colmado en un primer momento por hispanistas, si bien posteriormente habría un florecimiento y diversificación de los estudios en este campo (no en vano el historiador citado se había referido a nuestro país como la "tierra prometida" de la sociabilidad). O, ya situados en el ámbito hispano, de las lagunas que, pese a todo, se mantienen, de los interrogantes aún por despejar, de los retos que suscita el estudio de la sociabilidad informal, más escurridiza pero también con nuevos atractivos como los que derivan de sus vínculos con la movilización social. Se trata, en suma, de un realmente valioso estado de la cuestión.

El segundo capítulo, "Marco legal", aborda otra faceta imprescindible a la hora de estudiar la sociabilidad formal plasmada en el asociacionismo: partiendo de la reflexión sobre la trascendencia del derecho a asociarse libremente, la autora constata la renuencia, en las cartas de derechos y en las primeras constituciones liberales, a reconocerlo, una limitación que solo se corregiría plenamente con el siglo XX, como se aprecia en las declaraciones internacionales de la segunda mitad de la centuria, empezando por la de Derechos humanos de Naciones Unidas, aprobada en 1948. Esa necesaria introducción abre paso al estudio del proceso por el cual se fue abriendo camino en España, con grandes altibajos también, el reconocimiento legal de tal derecho, mostrándose con claridad cómo, en los dos primeros tercios del siglo XIX, lo que imperó fue la reticencia o la cortapisa a que los individuos pudieran asociarse libremente. Un sesgo que cambiaría con la Constitución democrática de 1869 y, ya en la Restauración, con la trascendental Ley de asociaciones de 1887 que fijaría por largo tiempo el marco normativo que reguló el ejercicio de este derecho. Tras exponer los cambios que introduce la legislación republicana de los años 1930, el capítulo se completa con un análisis bastante pormenorizado de lo que Elena Maza presenta como una "legislación coercitiva en tiempos de guerra y posguerra" en referencia a la inquina hacia el 
derecho de asociación (sindical, política, cultural, etc.) que mostraron desde los primeros momentos los militares sublevados en 1936 y a su materialización en diferentes disposiciones legales.

Pero el capítulo quizás más enjundioso y útil para el investigador es el tercero en donde la autora, bajo el rótulo de "evolución cuantitativa" traza en realidad una historia del asociacionismo en España y demuestra su profundo conocimiento de las variadas fuentes disponibles (que maneja aquí para, entre otras cosas, incluir tablas que permiten visualizar esa evolución entre mediados del siglo XIX y la II República) y de sus muchas insuficiencias así como de la bibliografía específica relativa a los diferentes tipos de asociaciones que nutren luego, con sus reglamentos, el apéndice documental. Del predominio neto de las asociaciones recreativas en el siglo XIX, seguidas a distancia por las mutualistas y de carácter instructivo, se pasará, en el primer tercio del XX a un panorama más complejo en el que hacen su entrada con fuerza las entidades patronales y, por lo que respecta a las obreras, las de carácter reivindicativo, de "resistencia al capital", lo cual da fe de los cambios que estaba experimentando la sociedad española y de los nuevos horizontes, expectativas y aprensiones que una mayor conflictividad social despertaba. Lo que no significa, sin embargo, que no aparezcan elementos de continuidad con la centuria anterior, como se advierte en la relativa pujanza que mantienen las entidades mutualistas. El periodo republicano introduciría algunos retoques en ese cuadro, potenciando aún más las asociaciones obreras y patronales a la vez que imprimió un cierto declive a las mutualistas. Todo cambiaría con la prohibición asociativa del franquismo, solo matizada por el aliento a algunos modelos del agrado del régimen, como el cooperativismo. Y la ley de asociaciones de 1964 tampoco ayudo a mejorar un panorama que la autora resume como "de desamparo y domesticación".

\author{
Rafael Serrano García \\ Instituto Universitario de Historia Simancas (Universidad de Valladolid)
}

